INSPECTION REPORT

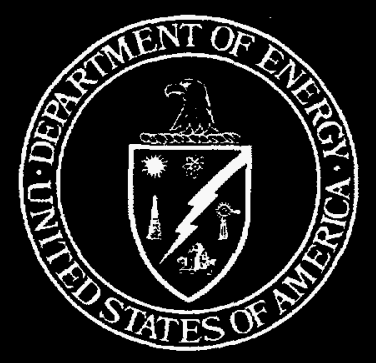

U.S. DEPARTMENT OF ENERGY OFFICE OF INSPECTOR GENERAL OFFICE OF INSPECTIONS

\section{INSPECTION OF THE} DEPARTMENT OF ENERGY'S CONFERENCE POLICIES AND PRACTICES

DECEMBER 1998

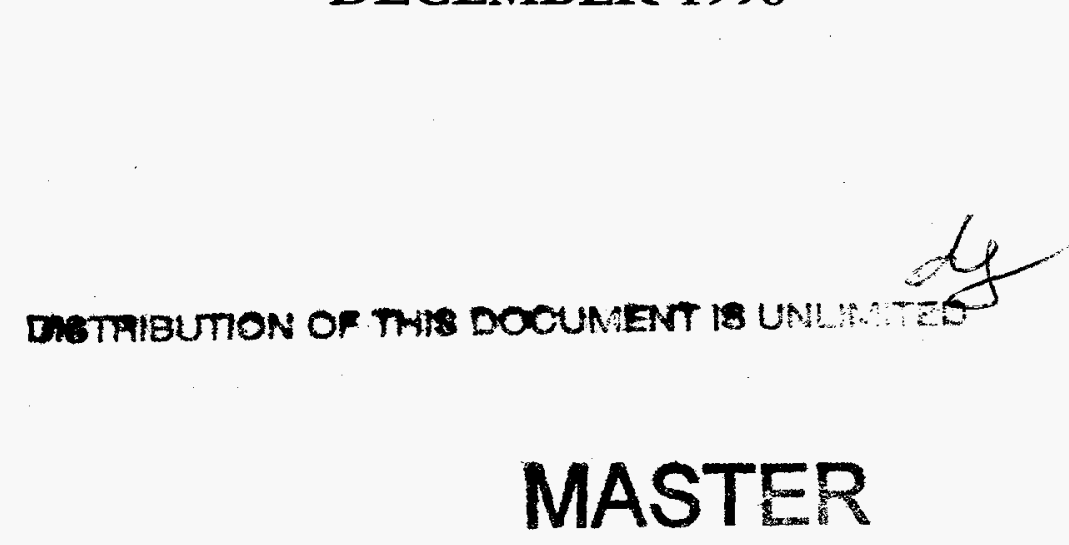




\section{DISCLAIMER}

Portions of this document may be illegible in electronic image products. Images are produced from the best available original document. 


\section{Department of Energy}

Washington, DC 20585

December 3, 1998

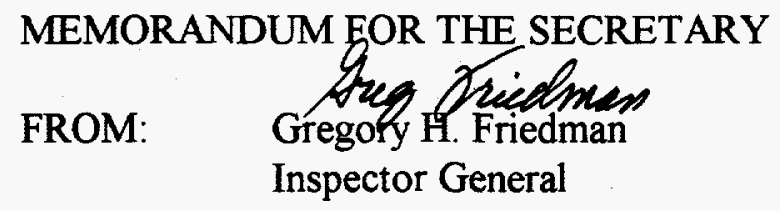

SUBJECT: $\quad$ INFORMATION: Report on "Inspection of the Department of Energy's Conference Policies and Practices"

\section{BACKGROUND}

The Department of Energy (DOE) is a recognized world leader in technological breakthroughs brought about by its many research and development programs. To further these technical and scientific achievements, the Department and its contractors conduct numerous conferences, meetings and symposiums every year. This inspection sampled conferencing practices at the Department's National Laboratories and evaluated the adequacy of Departmental conference policies and procedures.

\section{RESULTS OF INSPECTION}

The Department has not developed adequate policies and procedures regarding the conduct of its conference activities and the conference activities of its contractors. Guidance issued by the President, the Office of Management and Budget (OMB), and by the Federal Travel Regulation (FTR) requires that the Department minimize conference costs by establishing or revising existing procedures to ensure such costs are kept to a minimum. However, the inspection found that the Department does not have consistent Department-wide procedures in place to ensure that conference costs are minimized. As a result, weaknesses were found in some conference practices of the Department's contractors.

We recommended that the Office of Management and Administration in coordination with the General Counsel and Chief Financial Officer: (1) review the provisions of Presidential, OMB, and FTR guidance and develop Department-wide policies and procedures for all DOE and DOE contractor conferences that address conference site selection, minimizing attendance and reduction of overall costs of attending conferences; (2) develop policies regarding the approval level for all DOE and DOE contractor conferences; (3) develop policy to reduce duplicate reimbursement for conference meals provided as part of registration fees; (4) review the practice of charging a conference registration fee that includes unallowable costs; (5) establish policy that unallowable conference related costs be 
separately identified; (6) review the practice of DOE contractors using Federal funds to pay for conference banquet and meal expenses; and (7) determine the applicability of the Miscellaneous Receipt Act as it relates to the collection of conference related registration and exhibitor fees.

\section{MANAGEMENT REACTION}

Management concurred with the finding and five of the seven report recommendations, while partially concurring with the other two. Management stated that the Office of Management and Administration will forward a Departmental Notice regarding conferencing to the Secretary for approval by January 8, 1999. This Notice will include overall policy and procedures for DOE employees and contractors to follow when sponsoring or attending conferences.

\section{Attachment}

cc: Acting Deputy Secretary

Under Secretary 
TABLE OF CONTENTS

\section{Overview}

Introduction and Objective......................................... 1

Observations and Conclusions...................................... 3

The Department Lacks Adequate Policies and Procedures Necessary to Provide for Control Over the Cost of its Conference Activities

Details of Finding.

Recommendations and Comments 19

\section{Appendices}

I. Scope and Methodology

II. Actions Taken by Assistant Secretarial Offices and Two Operations Offices to Implement Conferencing Policies. 
INTRODUCTION AND OBJECTIVE
The Department of Energy (DOE), including its contractors, is a recognized world leader in technological breakthroughs brought about by its many research and development programs. To further these technical and scientific efforts, the Department and its contractors (which includes several National Laboratories), conduct numerous conferences, meetings, and symposiums each year. The themes of these conferences generally include complex and diverse topics such as Atomic Physics, Gammasphere Physics, Mapping Gene Sequencing, the Advanced Light Source, Exotic Nuclei, and Low Temperature Superconductors. These conferences, meetings, and symposiums are attended by representatives from the Department and the Department's contractors, as well as representatives from the private sector and domestic/foreign academic institutions.

The Department's conference activities include meetings (1) sponsored and managed directly by the Department; (2) co-sponsored by the Department but managed by Department contractors; and (3) sponsored and managed by organizations outside the Department where DOE Federal and contractor employees attend. The full scope and cost of the Department's conference activities is not available because of the diverse sponsorship of these conferences, and because there is no central source of Department-wide information on this subject. During Fiscal Year 1996, and the first half of Fiscal Year 1997, DOE reported to Congress that 293 conferences were sponsored by the Department. However, the inspection disclosed that this number significantly understates conference activity because it excludes conference activities of many of DOE's prime contractors. For example, at one Department contractor site, 25 DOE contractor conferences conducted in Fiscal Year 1996 were not included in the Department's report to Congress.

Our inspection initially examined the Department's conference activities at the Lawrence Berkeley National Laboratory (Berkeley). Specifically, we found that several questionable payments were made by the Berkeley Cashier's Office for conference-related expenses. Additional inquiries revealed that allowable and unallowable conference receipts were being commingled in Berkeley's Letter of Credit account. Berkeley conference 
management officials said they did not have an accounting system in place which could readily reconcile sources and uses of funds for allowable and unallowable conference costs. As a result of our initial inquiries, Berkeley conference management officials established a process in 1995 where two financial accounts were established within the Letter of Credit for each conference. One account was designated for allowable income and expenses, while the other account was designated for unallowable income and expenses.

A Berkeley Internal Audit issued in January 1995 made several recommendations to improve LBNL conference management practices after several control weaknesses were found to exist in the processing of invoice payments and cash receipts, and in preventing unallowable costs from being incurred or claimed. A DOE Office of Inspector General Report, Number WR-V-96-21, issued in September 1996, found that Berkeley was using its Letter of Credit to finance unallowable costs, and that conference registration fees collected to pay unallowable costs were commingled with Departmental funds in the special bank account. In response to these concerns, Berkeley established a separate bank account outside of the Letter of Credit to deposit conference registration fees.

In 1997, we expanded our inspection by sampling conference practices at other National Laboratories, and evaluating the adequacy of the Department of Energy's conference policies and procedures. Our inspection objectives were to determine: (1) whether the Department has developed adequate policies and procedures regarding the conduct of its conference activities and the conference activities of its contractors; and (2) if the conferencing practices of Department contractors are consistent with existing requirements and guidance related to the administration of conference activities and the use of Federal funds.

Recently, the Office of Inspector General also issued a report titled "The U.S. Department of Energy's X-Change 1997: The Global D\&D Marketplace Conference" which identified a lack of Departmental policy on the funding of conferences, and questionable fiscal practices associated with the X-Change Conference. 
OBSERVATIONS AND CONCLUSIONS
Our inspection found that the Department of Energy has not developed adequate policies and procedures regarding the conduct of its conference activities and the conference activities of its contractors. Presidential guidance issued in a February 10, 1993, memorandum to all Executive Departments and Agencies stated that strict fiscal responsibility must be exercised when selecting conference sites and conference attendees. The Office of Management and Budget (OMB), in issuing instructions under OMB Bulletin 93-11 regarding the implementation of this guidance, established as policy that Executive Departments and Agencies were not to spend "hard-earned tax dollars in ways that may appear to be improper." OMB Bulletin 93-11 specifically required that Executive Departments and Agencies minimize conference costs and establish or revise existing procedures to select conference sites and make other conference arrangements to ensure conference costs are kept to a minimum. This Bulletin specifically stated that "conference costs" included all costs paid by the Government, whether paid directly by a Government agency or reimbursed by the Government to contractors or others for a conference.

However, over five years after the original Presidential guidance, the Department of Energy still does not have consistent Department-wide procedures designed to assure that strict fiscal responsibility is applied to the Department's conference activities and the conference activities of its contractors. As a result, we found that weaknesses exist in some conferencing practices of Department contractors. Although there was some question as to whether the Department required its contractors to comply with the guidance and policy of the President and OMB; we found that some contractor conference practices did not appear to be consistent with the principles and concepts contained in this guidance and policy. These include:

- Some non-DOE conference facilities are being selected by National Laboratories without evaluating or documenting the cost of alternative conference sites.

- Some conferences were attended by many DOE-funded participants, however, we could not identify any Departmental policy which ensures that 
the number of conference participants is kept to a minimum.

In addition, some conferencing practices of Department contractors may not be consistent with Federal policy on the use of Federal funds. Specifically:

- A National Laboratory collected and used conference registration and exhibitor fees in a manner that may not be consistent with the provisions of the Miscellaneous Receipts Act or the provisions of its management and operating contract.

- DOE and DOE contractor employees have attended DOE-sponsored conferences where meals have been provided through conference registration fees, however, some conference participants' per diem have not been properly reduced.

- While sponsoring conferences, National Laboratories have used conference registration fees paid by other Federally-funded organizations to cover the cost of entertainment (recreational and social events), a practice that may not be consistent with the principle established by the U.S. Comptroller General that Federal funds cannot be used for entertainment unless specifically authorized by statute.

- Some banquets associated with National Laboratories' conferences appear to be primarily entertainment and social activities where alcohol was served, a practice that may not be consistent with the Comptroller General principle that meals should not be paid for with Federal funds unless the meals include essential formal discussions, lectures or speeches associated with the conference.

Given the magnitude of conferencing activities in DOE, we concluded that the Department should comply with both the letter and the spirit of the Presidential guidance and OMB policy by assuring that strict financial responsibility is 
applied to all the Department's conference activities, including those of its contractors. Further, as the Department proceeds to implement the requirements of the Government Performance and Results Act of 1993, the performance expectations for both DOE. Federal and DOE contractor conference activities needs to be better defined. 


\section{The Department Lacks Adequate Policies and Procedures Necessary to Provide for Control Over the Cost of its Conference Activities}

Presidential Guidance and OMB Policy Require the Department to Exercise Strict Financial Responsibility and Minimize Conference Costs
On February 10, 1993, the President of the United States issued a memorandum that provides guidance to the Heads of Executive Departments and Agencies regarding the need to reduce the cost of conferences. This memorandum states that, "The public interest requires that agencies exercise strict fiscal responsibility when selecting conference sites," and that ". . . agencies are not to select conference sites without evaluating the cost differences of prospective locations." This memorandum also states that "When agency representatives attend conferences sponsored by others, the agency must keep its representation to a minimum consistent with serving the public's interest." In addition, this memorandum states that "[t]he Office of Management and Budget, after consultation with the agencies, will issue further directives necessary to implement this requirement."

On April 19, 1993, the Office of Management and Budget issued OMB Bulletin 93-11, Subject: "Fiscal Responsibility and Reducing Perquisites." This bulletin, which applies to all Executive Departments, states that "[a]s American taxpayers are being asked to make a contribution to reducing the deficit it is imperative that we not spend their hard-earned tax dollars in ways that may appear to be improper," and that "[i]t is the responsibility of every Department and agency to ensure compliance with the President's policies and attached guidance both in spirit and in fact."

OMB Bulletin 93-11 was intended to apply to all costs paid by the Government for a conference, whether paid directly by agencies or reimbursed by agencies to travelers or others associated with the conference, e.g., speakers, contractors, etc. "Conferences" were defined as meetings, retreats, training activities, and other gatherings which involve travel outside the attendees' permanent duty stations. "Conference costs" were defined as "all costs" paid by the Government for a conference, including, but not limited to, travel to and from the conference, ground transportation, lodging, meals and incidental costs, meeting room and audiovisual costs, registration fees, speaker fees, and conference-related administrative fees; and the cost of employees' time spent at the conference and traveling to and from the conference. An OMB Policy Analyst who 
authored the portion of the Bulletin relating to conferences advised that this Bulletin specifically applied to DOE management and operating contractors, as well as DOE Federal employees. He further advised that, in his opinion, "the M\&O contractor that operates a facility like the Hanford Site or a National Laboratory is acting as an extension of a Government agency, and that they are required to spend Government funds according to Government policy."

OMB Bulletin 93-11 requires agencies to select conference sites that minimize conference costs, and when agency representatives attend conferences sponsored by others, the agency should keep its representation to a minimum consistent with serving the public's interest. Specifically, the Bulletin requires that agencies: (1) establish or revise existing procedures to select conference sites, and in making other conference arrangements, to ensure that conference costs are kept to a minimum; (2) document the alternatives considered and rationale used in selecting conference sites; and (3) establish or revise existing internal policies and procedures for determining the number and identity of persons to send to conferences.

On October 29, 1993, 41 CFR Part 301 (the Federal Travel Regulation), was amended to include provisions for conference planning as identified in OMB Bulletin 93-11. This amendment requires agencies to establish policies governing conference site selection, and policies and procedures designed to reduce the overall cost of attending conferences. This amendment also requires that a senior agency official authorize Government sponsorship or co-sponsorship of a conference which involves travel by 30 or more Federal civilian employees, and requires that a senior agency official authorize a conference at a selected site when the conference involves travel by 30 or more Federal civilian employees.

Policies and Procedures Relating to Conference Activities Expired and Were Canceled in March 1994
On March 10, 1993, the Department of Energy issued DOE Notice 1130.3, "Departmental Conference Activity," to implement the revised responsibilities and authorities for approval of Department of Energy-sponsored and co-sponsored conferences, and the provisions of the February 10, 1993, Presidential memorandum. This notice stated that "Departmental Elements are reminded that . . . organizations are to provide in each conference request a rationale and justification for site selection; a cost 
The Department Does Not Have Adequate Department-wide Conference Policies and Procedures comparison of alternative sites considered; and certification that the site selected is the most cost-effective considering costs such as travel, per diem, and conference logistics." This notice also addressed the need to exercise strict financial responsibility when determining the number of DOE representatives to attend non-DOE-sponsored or cosponsored conferences. However, DOE Notice 1130.3 expired on March 10, 1994. Similarly, on March 25, 1994, DOE Order 1130.7B, "DEPARTMENTAL CONFERENCE ACTIVITY," which represented the only formal policies, procedures, and responsibilities for the management of conferences within the Department, was canceled as part of the Department's effort to reduce the "burden and volume" of internal regulations.

Despite the policy established by the President in 1993 and the OMB implementing guidance, the Department of Energy does not have adequate Department-wide policies and procedures designed to assure that strict fiscal responsibility is applied to the Department's conference activities, and the conference activities of its contractors. In an effort to address the cancellation of DOE Order 1130.7B and comply with the requirements of the Presidential memorandum, OMB Bulletin 93-11, and the Federal Travel Regulation; the Assistant Secretary for Human Resources and Administration (HR) delegated the authority for conference approval in a May 24, 1994, memorandum titled "Approval of Department of Energy Conferences." This memorandum had the specific effect of delegating conference approval authority formerly held by the Secretary of Energy and/or HR, to Secretarial Officers, Managers of Operations Offices, and Administrators of the Power Marketing Administrations. This memorandum authorized Secretarial Officers, Managers of Operations Offices, and Administrators of the Power Marketing Administrations to approve all Department of Energy conferences which are sponsored or co-sponsored by their respective organizations, regardless of the total estimated cost or the number of Departmental and/or contractor attendees. This memorandum also authorized Secretarial Officers and Managers of Operations Offices to determine the approval level for their respective management and operating contractor conferences, and states that "All conferences sponsored or cosponsored by Departmental 
Elements are to fully comply with the conference policy contained in [the Federal Travel Regulation] (summary of major provisions attached)."

The May 24, 1994, memorandum exists today as the only Department-wide policy statement on conference activities. However, while this memorandum delegates authority to approve conferences and provides a summary of the major provisions of the Federal Travel Regulation, it relies upon Secretarial Officers, Managers of Operations Offices, and Administrators of the Power Marketing Administrations to establish local policies and procedures for DOE and DOE contractor conferences that would implement the Presidential and OMB guidance.

This policy memorandum did not require standardized, consistent Department-wide conference policies. During a review of the actions taken by the Office of Energy Research (ER), Defense Programs (DP), Environmental Management (EM), and the Oakland and Albuquerque Operations Offices to implement the requirements of the May 24, 1994, memorandum, we found that local policies and procedures for DOE and DOE contractor conferences had not been consistently established. For example, EM and the Albuquerque Operations Office did issue policy on the approval of Department of Energy conferences and meetings. However, we were unable to identify actions taken by the Office of Energy Research, Defense Programs, and the Oakland Operations Office to develop: (1) procedures for the approval of DOE and DOE contractor conferences; (2) procedures to implement the conference policy contained in the Federal Travel Regulation; (3) procedures to reduce the overall cost of attending conferences; or (4) goals for their conference activities. The actions taken by ER, DP, EM, Albuquerque, and Oakland are discussed in more detail in Appendix II.

Some Conferencing Practices of Department Contractors Did Not Appear to be Consistent with the Guidance and Policy of the President and $\mathrm{OMB}$
Some conferencing practices of Department contractors did not appear to be consistent with the Presidential memorandum and OMB policy regarding the selection of conference sites, the limitation on the number of conference attendees, or the minimization of conference costs. Specifically, our inspection found: 
- National Laboratories have hosted conferences at various sites, including many DOE-owned as well as some non-DOE facilities. Non-DOE conference facilities were selected without evaluating and documenting the cost of alternative conference sites as required by Presidential guidance and OMB Bulletin 93-11. During interviews with National Laboratory conference coordinators, we found no evidence of any cost, logistics, or other analysis that was completed to justify the non-DOE conference sites selected. In a sample of seven non-DOE conference sites selected by four National Laboratories, there was no documentation identifying the cost of the alternative conference sites that were considered.

- Significant numbers of DOE and DOE-funded contractor participants have attended conferences sponsored both by Department contractors and by organizations outside the Department. While conference attendance is essential for the exchange of information which furthers the Department's technical and scientific efforts, Government policy requires that the Department establish internal procedures which minimize the number of conference attendees consistent with accomplishing the Department's goals. During our inspection, we identified conferences which were attended by many DOE-funded participants, but we could not identify any Departmental policy which ensures that the number of conference participants is kept to a minimum.

For example, 525 DOE and DOE contractor employees attended the Particle Accelerator Conference 1997 (PAC'97) that was sponsored by the Canadian TRIUMF Laboratory in association with the University of Maryland, and held during May 1997, in Vancouver, British Columbia. The estimated cost to the Department for DOE and DOE contractor attendance at this conference was approximately $\$ 1$ million. This included registration fees, air fare, per diem, and lodging, but excluded salaries for the 525 DOE and DOE contractor participants. Although precise salary costs were not available, we estimated that 
inclusion of such costs would have increased the total overall cost of the conference by at least $\$ 600,000$. The DOE and DOE contractor employees attending PAC'97 came from the following organizations:

Organization

Number of

Participants

Argonne National Laboratory

Brookhaven National Laboratory

Lawrence Berkeley National Laboratory

77

Fermi National Laboratory

Los Alamos National Laboratory

64

Lawrence Livermore National Laboratory

27

Stanford Linear Accelerator Center

Oak Ridge National Laboratory

Sandia National Laboratory

Thomas Jefferson National

Accelerator Facility

DOE Headquarters

TOTAL

In another example, $176 \mathrm{DOE}$ and DOE contractor funded participants from nine National Laboratories attended the "Human Genome DOE Contractor - Grantee Meeting" that was sponsored by Berkeley and held in Santa Fe, New Mexico, during January 1996. The estimated total cost to the Department for DOE and DOE contractor attendance at this conference was $\$ 338,000$ in registration fees, salaries, per diem, and lodging. Airfare was not included in this estimate and would represent an additional cost.

We make no judgment whether the number of DOE laboratory personnel attending these and other conferences was excessive. However, there was no evidence that Laboratory management considered the appropriateness of the attendance of all the participants, consistent with the Presidential and $O M B$ guidance to minimize conference attendance. 
Some conferencing practices of Department contractors may not be consistent with Federal policy on the use of Federal funds. Specifically:

- Berkeley collected and used conference registration and exhibitor fees in a manner that may not be consistent with the Miscellaneous Receipts Act or the specific terms of its management and operating contract. For example, we found several instances in a sample of Fiscal Year 1996 Berkeley conferences where income from conference registration and exhibitor fees exceeded the cost of the services they were collected for, resulting in excess funds. Specifically, excess funds in the amount of $\$ 8,826$ were transferred by Berkeley from a conference account to a Berkeley operating account. In another instance, excess funds in the amount of $\$ 8,550$ were transferred from a Berkeley unallowable conference account to a Berkeley allowable conference account. We note that the deposit of registration and exhibitor fees to a separate conference account outside of the letter of credit is the current practice at Berkeley, and if excess unallowable account funds remain at the end of a conference, those funds are applied to the allowable conference account. The Miscellaneous Receipts Act (31 U.S.C. 3302), which was applicable to Berkeley through the provisions of its management and operating contract, may require that these types of excess funds be deposited into the General Fund of the Treasury.

The Department's conferencing activities generate significant registration and other fees. Given the experience at Berkeley, we concluded that the Department needs to review the broader issue of whether all conference registration and other fees collected by the Department's contractors who are subject to the requirements of the Department's Chief Financial Officer's Accounting Handbook (Accounting Handbook), should be deposited to the Treasury as miscellaneous receipts. Specifically, the Accounting Handbook requires that collections made by the Department's integrated contractors are to be accounted for as either: (a) an appropriation reimbursement; (b) reductions of cost; or (c) Treasury 
General Fund miscellaneous receipts. Appropriation reimbursements are required to be deposited directly to the Treasury as a credit to a DOE Appropriation Account. Collections accounted for as reductions of cost may be deposited into the contractor's DOE special financial institution account. However, collections accounted for as reductions of cost must be budgeted as offsets to cost, or must constitute items such as: (1) proceeds from personal property sales; (2) collections from other DOE contractors for cash work under $\$ 100,000$; (3) refunds; or (4) rebates. Collections not covered as either appropriation reimbursements or reductions of cost are to be deposited into a General Fund miscellaneous receipt account.

In the case of conference registration and exhibitor fees collected by the Department's contractors, this criteria has not been met. Therefore, based on the criteria contained in the Accounting Handbook, we believe the Department should evaluate the collection of conference registration and exhibitor fees by the Department's integrated contractors, and determine the extent to which all such collections would be subject to deposit as a miscellaneous receipt.

- DOE and DOE contractor employees have attended conferences sponsored by National Laboratories where meals have been paid for through conference registration fees. However, we found in some instances that conference participants' per diem has not been reduced when such meals have been paid for through conference fees. As a result, some individual employees were reimbursed twice for subsistence expenses while others incorrectly reduced per diem claimed. In a sample of 71 travel vouchers from two DOE-sponsored conferences attended by participants from seven National Laboratories as well as DOE employees, we found that 22 conference participants, or 31 percent, did not make appropriate per diem reductions. We believe the Department needs to establish a policy whereby DOE-sponsored conference registration forms clearly indicate specific meals that are provided as part of a conference registration fee, and consider requiring a copy of the conference registration form be filed with travel claims submitted by DOEfunded conference participants. 
- National Laboratories have used conference registration fees paid by other Federally-funded organizations to cover the cost of entertainment (including recreational and social events), a practice that may not be consistent with Federal appropriations law and the Comptroller General principle that entertainment may not be paid with Federal funds unless authorized by statute. Specifically, "Principles of Federal Appropriations Law," states that:

"Just as the entertainment of government personnel is generally unauthorized, the entertainment of non-government personnel is equally impermissible. The basic rule is the same regardless of who is being fed or entertained: Appropriated funds are not available for entertainment, including free food, except under specific statutory authority."

We found that many Federally-funded organizations have sent representatives to Berkeley sponsored conferences and have paid registration fees to Berkeley with Federal moneys. However, portions of these registration fees have been used to pay for unallowable conference costs, such as alcohol and entertainment. Berkeley has established a practice of advertising a single registration fee per conference, requiring that conference participants pay such a fee as a means of defraying both allowable and unallowable costs expected to be incurred during the conference. Federally-funded organizations such as the Los Alamos National Laboratory (Los Alamos), Lawrence Livermore National Laboratory (Livermore), and the Stanford Linear Accelerator have paid the Berkeley registration fees through the issuance of a single institutional check for each of their conference participants.

For example, Berkeley sponsored a "Human Genome DOE Contractor - Grantee Meeting," in Santa Fe, New Mexico, during January 1996. According to Berkeley conference files, 362 participants attended this meeting, where 267, or 74 percent, were from Federally-funded institutions. According to the Berkeley Conference Coordinator, registration fees of $\$ 240$ per Federallyfunded participant were collected and deposited in the 
Letter of Credit conference account. The Berkeley Conference Coordinator told us the initial conference budget allocated $\$ 80$ per person (or $\$ 20,800$ from Federally-funded participants) which was to be deposited to the unallowable Letter of Credit conference account to pay for expenses such as breaks, a reception, and alcohol. However, alcohol expenses were never incurred as a no-host bar was used, and excess unallowable account funds were moved to the allowable conference account. ${ }^{1}$

In fact, we found that the practice of charging a single conference registration fee which may include items of unallowable costs appears to be common, and is used by other National Laboratories. Examples of other Department contractors that include items of cost in conference registration fees that appear to be questionable are as follows:

\begin{tabular}{|c|c|c|c|}
\hline Conference & Sponsor & $\begin{array}{c}\text { Registration } \\
\text { Fee } \\
\end{array}$ & $\begin{array}{l}\text { Questionable } \\
\text { Costs }\end{array}$ \\
\hline $\begin{array}{l}\text { Trapped Charged } \\
\text { Particles }\end{array}$ & Livermore & $\$ 235.00$ & $\begin{array}{l}\text { Boat Cruise } \\
\text { Picnic } \\
\text { Concert }\end{array}$ \\
\hline $\begin{array}{l}\text { 4th Conference on } \\
\text { Inorganic } \\
\text { Membranes }\end{array}$ & $\begin{array}{l}\text { Oak Ridge } \\
\text { National } \\
\text { Laboratory }\end{array}$ & $\$ 500.00$ & $\begin{array}{l}\text { Reception } \\
\text { Theater } \\
\text { Tennessee BBQ }\end{array}$ \\
\hline $\begin{array}{l}\text { Biotechnology } \\
\text { Symposium }\end{array}$ & $\begin{array}{l}\text { National } \\
\text { Renewable } \\
\text { Energy } \\
\text { Laboratory }\end{array}$ & $\$ 350.00$ & Wine Tasting \\
\hline $\begin{array}{l}\text { Workshop on Deep } \\
\text { Inelastic Scattering }\end{array}$ & $\begin{array}{l}\text { Argonne } \\
\text { National } \\
\text { Laboratory }\end{array}$ & $\$ 340.00$ & $\begin{array}{l}\text { Social Hour } \\
\text { Boat Tour }\end{array}$ \\
\hline ISCOPE '97 & Los Alamos & $\$ 300.00$ & $\begin{array}{l}\text { Reception } \\
\text { Yacht Cruise }\end{array}$ \\
\hline
\end{tabular}

${ }^{1}$ Office of Inspector General Report, Number WR-V-96-21, addressed the issues of Berkeley using the Letter of Credit to finance unallowable costs; and commingling registration fees, which were collected to pay the unallowable costs, with Departmental funds in the special bank account. 
Additionally, we found an example where entertainment and social events were advertised as part of a DOE National Laboratory's Conference Announcement. Specifically, the XIX International Linac Conference (LINAC98), organized by Argonne National Laboratory in association with Fermi National Accelerator Laboratory, was held during August 1998, in Chicago, Illinois, with a conference registration fee of $\$ 550$. LINAC98 "Conference Information" states that conference social events are included in the conference registration fee, and includes a box lunch during an afternoon at the Chicago Botanic Garden, an outdoor reception and barbecue, followed by a concert with a world renowned cello soloist.

We recognize that there is a distinction between Government and corporate practice regarding entertainment expenses, and that entertainment as a business-related expense is an established practice in the corporate sector. We also recognize that significant business can be conducted informally at receptions and social events associated with conferences. However, the policy underlying the rule for the use of Government funds, is summarized in an excerpt from Comptroller General decision B-223678, June 5, 1989, which states that:

"The theory is not so much that these items can never be business-related, because sometimes they clearly are. Rather, what the decisions are really saying is that, because public confidence in the integrity of those who spend the taxpayer's money is essential, certain items which may appear frivolous or wasteful -however legitimate they may in fact be in a specific context -- should, if they are to be charged to public funds, be authorized specifically by the Congress."

"Principles of Federal Appropriations Law" provides additional Federal policy on the use of Government funds for entertainment, and states that "Except where specifically appropriated for, entertainment cannot normally be said to be necessary to carry out the 
purposes of an appropriation." Therefore, the practices described above should be reviewed by the Department.

- DOE contractors, specifically several National Laboratories, sponsored conferences using registration fees to provide banquets for conference participants. Banquets associated with some National Laboratory conferences appeared to be primarily entertainment and social activities. The use of Federal funds in these instances may not be consistent with the Comptroller General principle that meals cannot be paid for with Federal funds unless the meal includes essential formal discussions, lectures, or speeches associated with the conference. Specifically, during our review of conferences hosted by a sample of National Laboratories, we found some banquets that were advertised as "social events," or that included boat cruises, the use of facilities distant from the conference site (e.g. an Indian pueblo, a museum, an art institute, and a craft center), entertainment, and the serving of alcohol.

For example, the Thomas Jefferson National Accelerator Facility sponsored the HEPiX meeting at Newport News, Virginia, in October 1997. Included in the $\$ 125$ conference registration fee was payment for an evening reception, banquet, and tour of the Hampton Roads Harbor aboard a schooner ship. These activities were specifically identified as "Social Event - Cruise and dinner" in the HEPiX Conference "Final Programme."

Further, Berkeley sponsored an "Official banquet" with a budget of $\$ 4,500$, which was approved by the Berkeley Conference Coordinator as part of the DOE/BES Workshop that was held in San Antonio, Texas, on November 3-4, 1995. This "Official banquet" began on November 3, 1995, after the conference recessed for the day, at a location that was distant from the conference site. In fact, Berkeley paid for the rental of a boat to transport conference participants to the banquet site, the "Southwest Crafts Center," which was rented specifically for this event. After arriving at this location, 60 banquet participants were provided dinner and were entertained by a mariachi band. The total cost of the banquet was $\$ 4,357$, including $\$ 805$ in alcohol and 
$\$ 1,275$ for rental of the Crafts Center. During an interview with the Berkeley Conference Coordinator, the Conference Coordinator said that conference participant registration fees of $\$ 110$ per person were used in part to pay for the "Official banquet" costs, which included the alcohol, the boat ride, and the entertainment. The Conference Coordinator also said that the banquet agenda included a speaker.

The Comptroller General has determined that reimbursement for meals provided to Federal employees as part of a formal discussion at a meeting is authorized only if the meals are incidental to the meeting; attendance of the employee at the meals is necessary for full participation in the business of the meeting; and the employee is not free to partake of meals elsewhere without being absent from essential formal discussions, lectures, or speeches concerning the purpose of the meeting.

Our review of travel vouchers relating to two conferences, indicated that a number of participants had not offset the meals received at social events and banquets associated with the conferences. Offset for the cost of such meals could ameliorate some of the concerns regarding the possible inappropriate use of Federal funds, as discussed above. The practice of using Federal funds for conference banquets should be reviewed by the Department, and a determination made regarding the appropriateness of using Federal funds in such circumstances.

We concluded that the conditions noted during the inspection could have been avoided had the Department developed and implemented a comprehensive policy regarding conferencing, consistent with Presidential and $\mathrm{OMB}$ direction. 
We recommend that the Director of the Office of Management and Administration, in coordination with the Chief Financial Officer and the General Counsel:

1. Review the provisions of the Presidential memorandum, OMB Bulletin 93-11 and the Federal Travel Regulation; and develop specific Department-wide policies and procedures for all DOE and DOE contractor conferences which address the selection of conference sites, the cost differences of alternative conference sites considered, the minimization of conference attendance, and the reduction of the overall cost of attending conferences.

2. Develop specific Department-wide policies and procedures for the approval level of all DOE and DOE contractor conferences, and ensure that the approval of these conferences is maintained at a senior level within the Department.

3. Develop specific policy which requires that DOE and DOE contractor conference registration forms identify the meals that are included in conference registration fees, and consider requiring that a copy of the conference registration form be filed with travel claims submitted by DOE-funded conference participants.

4. Review the practice of advertising a single registration fee per conference that includes both allowable and unallowable conference expenses, and determine the extent to which this practice should be consistent with the Comptroller General's principle that Federal funds may not generally be used for the payment of entertainment and other unallowable costs.

5. Establish policy on the development of conference registration fees by Department contractors, with particular attention given to the identification of allowable and unallowable costs as two separate registration fee components.

6. Review the practices of DOE contractors as they relate to the use of Federal funds for the payment of banquet and meal expenses at conferences and meetings, and (1) determine the extent to which these practices should be consistent with OMB Bulletin 93-11 and the 
decisions of the Comptroller General regarding the use of Federal funds, and (2) establish policy for all DOE and DOE contractor conferences regarding banquet and meal expenses.

7. Determine the applicability of the Miscellaneous Receipts Act as it relates to the collection of registration and exhibitor fees for DOE and DOE contractor conferences; develop a specific policy regarding the treatment of registration and exhibitor fees; and ensure that all DOE and DOE contractor conference coordinators are aware of the provisions of this policy. In developing this policy, consider the question of whether all conference registration fees collected by Department contractors should be deposited to the Treasury as miscellaneous receipts.

Management Comments

Inspector Comments
Management concurred with the finding and five of the seven report recommendations, while partially concurring with the other two. Management stated that the Office of Management and Administration will forward a Departmental Notice regarding conferencing to the Secretary for approval by January 8,1999 . This Notice will include overall policy and procedures for DOE employees and contractors to follow when sponsoring or attending conferences.

We consider management's reaction to be responsive to the inspection recommendations. 
Scope

Methodology
We reviewed the practices used by Berkeley in managing, administering, and funding its technical and scientific conferences, with particular emphasis on the allowability of conference costs, the selection of conference sites, and Berkeley's compliance with the provisions of their management and operating contract. We also reviewed other DOE contractor conference practices and Federal policy relating to conference costs and activities. In reviewing these conference practices, we evaluated:

1. Federal policies regarding the use of Government funds for conferences and conference related expenses. This evaluation included policy and guidance established by: (1) the President of the United States; (2) the Office of Management and Budget; (3) decisions of the Comptroller General of the United States; and (4) the Federal Travel Regulation.

2. Berkeley's policy on the use of Government funds for conferences and conference related expenses.

3. The process used by Berkeley to fund and pay for allowable and unallowable conference expenses.

4. The process used by Berkeley and other National Laboratories relating to the selection of conference sites and the use of Federal funds to pay for unallowable costs through conference registration fees.

5. Department of Energy policies, procedures, and guidance relating to the approval of conferences and selection of conference sites.

To accomplish the inspection objectives, we reviewed:

(1) a February 10, 1993, memorandum from the President of the United States, titled "Government Fiscal Responsibility and Reducing Perquisites;" (2) OMB Bulletin 93-11; (3) the Federal Travel Regulation; (4) DOE Orders and Notices relating to financial management and conference planning; (5) conference and travel expense reimbursement decisions of the Comptroller General of the United States; (6) the Federal Acquisition Regulation (FAR); (7) the Department of Energy Acquisition Regulation (DEAR); (8) the DOE Accounting Handbook; (9) a sample 
of Berkeley conference files for conferences sponsored or hosted by Berkeley during Fiscal Years 1994 through 1997, with primary emphasis on a judgmental sample of 12 of 46 conferences held in Fiscal Year 1996; (10) financial, travel, and conference related contract provisions of the management and operating contract with the Regents of the University of California for the management of Berkeley; and (11) conference practices at other DOE National Laboratories.

As part of our review, the Office of Inspections obtained information at the Oakland Operations Office and Berkeley. We also interviewed Department of Energy Headquarters officials, and officials at several Operations Offices and National Laboratories; including among others the Oakland Operations Office, Berkeley, Los Alamos National Laboratory, and Lawrence Livermore National Laboratory. This inspection was conducted between March 1995 and July 1998.

This inspection was concluded in accordance with the "Quality Standards for Inspections" issued by the President's Council on Integrity and Efficiency. 


\section{Appendix II - Actions Taken by Assistant Secretarial Offices and Two Operations Offices to Implement Conferencing Policies}

\section{Actions Taken by Assistant Secretarial Offices}

Actions Taken by the Oakland Operations Office
The Assistant Secretary for Environmental Management issued an April 20,1995, memorandum to all Deputy Assistant Secretaries which addressed the "Delegation of Authority for EM Headquarters Conference Activities." This memorandum identified an "EM Headquarters Conference Approval Policy" and provided an "EM Conference Approval Request Format." The EM policy stated that each Deputy Assistant Secretary was to ensure that all EM conference activities and justifications under their purview: (1) explicitly demonstrate that such activities are reduced to a minimum; (2) are considered as the only way to satisfy programmatic requirements; and (3) are provided in the most cost effective manner. The "EM Conference Approval Request Format" contained a section titled "CONCERNS THAT INFLUENCE APPROVAL OF A CONFERENCE," and addressed the need for information on areas of concern such as the purpose and objectives of the conference, the conference location, and the number of conference attendees. However, we were unable to identify any action taken by either the Office of Energy Research or the Office of Defense Programs in response to the May 24, 1994, memorandum.

We were unable to identify any action taken by the Oakland Operations Office to develop policies and procedures in accordance with the May 24, 1994, memorandum. Responding to the Office of Inspections, the Oakland Operations Office attributes the absence of specific action (i.e., policies, notification of contractors) to its interpretation that 41 CFR 301-16 (Federal Travel Regulation) upon which the requirements of the May 24, 1994, memorandum is based, was not applicable to contractors. This interpretation was concurred with by Oakland's legal staff in June 1997.

The Albuquerque Operations Office was not able to identify any action taken in response to the May 24, 1994, memorandum to develop procedures for the approval of DOE contractor conferences, or to reduce the overall cost of attending DOE contractor conferences. However, the Albuquerque Operations Office did develop a "Policy on Conference and Meeting Room Rentals and Food Services" for Operations Office conferences and meetings. This policy addressed conference and meeting room rental procedures and coffee/food service requests. This policy specifically addressed the issue of reducing the overall cost 
of attending Operations Office conferences by requiring meeting and conference organizers to check the availability of "no charge" meeting facilities, and by requiring justifications and cost estimates to rent other facilities if "no charge" facilities were not available. 


\section{CUSTOMER RESPONSE FORM}

The Office of Inspector General has a continuing interest in improving the usefulness of its products. We wish to make our reports as responsive as possible to our customers' requirements, and therefore ask that you consider sharing your thoughts with us. On the back of this form, you may suggest improvements to enhance the effectiveness of future reports. Please include answers to the following questions if they are applicable to you:

1. What additional background information about the selection, scheduling, scope, or procedures of the audit or inspection would have been helpful to the reader in understanding this report?

2. What additional information related to findings and recommendations could have been included in this report to assist management in implementing corrective actions?

3. What format, stylistic, or organizational changes might have made this report's overall message more clear to the reader?

4. What additional actions could the Office of Inspector General have taken on the issues discussed in this report which would have been helpful?

Please include your name and telephone number so that we may contact you should we have any questions about your comments.

Name Date

Telephone Organization

When you have completed this form, you may telefax it to the Office of Inspector General at (202) 586-0948, or you may mail it to:

Office of Inspector General (IG-1)

U.S. Department of Energy

Washington, D.C. 20585

ATTN: Customer Relations

If you wish to discuss this report or your comments with a staff member of the Office of Inspector General, please contact Wilma Slaughter at (202) 586-1924. 
The Office of Inspector General wants to make the distribution of its reports as customer friendly and cost effective as possible. Therefore, this report will be available electronically through the Internet at the following alternative address:

\section{Department of Energy Human Resources and Administration Home Page http://www.hr.doe.gov/ig}

Your comments would be appreciated and can be provided on the Customer Response Form attached to the report.

This report can be obtained from the

U.S. Department of Energy

Office of Scientific and Technical Information

P.O. Box 62

Oak Ridge, Tennessee 37831 